\title{
Germination of spores and growth of gametophytes and sporophytes of Rumohra adiantiformis (Forst.) Ching (Dryopteridaceae) after spore cryogenic storage ${ }^{1}$
}

\author{
FRANCIS MARIA ROCHO DE BRUM ${ }^{2}$ and AUREA MARIA RANDI ${ }^{2,3}$
}

(received: June 2, 2005; accepted: August 10, 2006)

\begin{abstract}
Germination of spores and growth of gametophytes and sporophytes of Rumohra adiantiformis (Forst.) Ching (Dryopteridaceae) after spore cryogenic storage). Rumohra adiantiformis (Forst.) Ching is a fern (Dryopteridaceae) used in floral arrangements. Spores sterilized in 15\% (v/v) solution of commercial sodium hypochlorite for 10 minutes and unsterilized spores were plunged in liquid nitrogen and held for 15 minutes and for 90 days. After the cryogenic treatments, spores were taken out of liquid nitrogen and rapidly thawed out in a water bath or slowly at room temperature and were cultured in Mohr's mineral solution as modified by Dyer, kept at $25 \pm 2{ }^{\circ} \mathrm{C}$ and a 16 -hours photoperiod. Statistical differences were not observed in the germination of unsterilized spores immersed or not immersed in liquid nitrogen, but when the spores were previously sterilized, a severe inhibition of germination was observed in cryopreserved spores. Faster mean germination time was observed for unsterilized spores cryopreserved in liquid nitrogen for 15 minutes. The germination of spores stored in liquid nitrogen for 90 days reached the maximum percentage after 12 days, while control spores reached their maximum percentage after 16 days. Levels of soluble sugars did not vary among treatments in gametophytes cultivated for 10 weeks after spore inoculation. The number of fronds and the length of the longest frond on sporophytes did not differ statistically among treatments. The relative growth rate of sporophytes grown from cryopreserved and control spores were not statistically different among treatments. Spores of $R$. adiantiformis immersed in liquid nitrogen for 15 minutes apparently produced phenotypically normal plants.
\end{abstract}

Key words - liquid nitrogen, Rumohra, storage.

RESUMO - (Germinação de esporos e crescimento de gametófitos e esporófitos de Rumohra adiantiformis (Forst.) Ching (Dryopteridaceae) após armazenamento criogênico de esporos). Rumohra adiantiformis (Forst.) Ching é uma pteridófita (Dryopteridaceae), usada em arranjos florais. Esporos esterilizados em solução de hipoclorito de sódio comercial a 15\% (v/v) durante 10 minutos ou esporos não esterilizados foram imersos em nitrogênio líquido por 15 minutos ou 90 dias. Após os tratamentos de conservação criogênica, esporos foram retirados do nitrogênio líquido e degelados rapidamente em banho morno ou à temperatura ambiente. Os esporos germinaram a $25 \pm 2{ }^{\circ} \mathrm{C}$ em fotoperíodo de 16 horas, em solução nutritiva de Mohr modificada por Dyer. Não ocorreram diferenças estatisticamente significativas na germinação de esporos não esterilizados imersos ou não em nitrogênio líquido, mas quando os esporos foram esterilizados, houve severa inibição da germinação dos esporos criopreservados. O menor tempo médio de germinação foi observado para esporos criopreservados por 15 minutos não esterilizados. A germinação de esporos armazenados em nitrogênio líquido por 90 dias atingiu o máximo após 12 dias e esporos do controle atingiram o máximo após 16 dias. Os níveis de açúcares solúveis não variaram entre os tratamentos, nos gametófitos de 10 semanas de cultivo a partir da inoculação dos esporos. Os números de frondes e as alturas das maiores frondes produzidas por plantas submetidas aos diferentes tratamentos não apresentaram diferenças estatisticamente significativas. As taxas de crescimento relativo dos esporófitos oriundos de esporos criopreservados e controle não difeririam estatisticamente entre os tratamentos. Esporos de $R$. adiantiformis imersos em nitrogênio líquido por 15 minutos aparentemente produziram plantas fenotipicamente normais.

Palavras-chave - armazenagem, nitrogênio líquido, Rumohra

\section{Introduction}

Rumohra adiantiformis (Forst.) Ching, a fern belonging to the Dryopteridaceae, grows in a variety of

1. Parte da dissertação do primeiro autor, Programa de Pós-Graduação em Biologia Vegetal da Universidade Federal de Santa Catarina.

2. Universidade Federal de Santa Catarina, Departamento de Botânica, 88040-900 Florianópolis, SC, Brasil.

3. Corresponding author: amrandi@ccb.ufsc.br habitats from bare sandy soil, to areas with bushes, in forests, and even on rocks. It occurs from sea level to altitudes above 2,400 $\mathrm{m}$ in the Peruvian Andes (Kato 1974, Tryon \& Tryon 1982). It produces homosporous, ellipsoidal, monolete, nonchlorophyllous and tuberculatesaccate spores forming green gametophytes with numerous rhizoids on the inferior central surface cushion (Tryon \& Tryon 1982).

This plant is popular in the composition of floral arrangements because of the exceptional longevity of 
the leaves after being cut and kept in a vase (Milton \& Moll 1988). In Florida (USA), the cultivation of $R$. adiantiformis for leaf harvest is accomplished under controlled conditions (Stamps et al. 1994). However, in countries such as the Republic of South Africa and Brazil, where natural populations of the species exist, the leaf harvest is done directly in the field (Milton \& Moll 1988).

Nutrients as well as other factors are implicated in the growth and development of gametophytes and sporophytes (Fernández et al. 1996, 1997, 1999). According to Camloh \& Gogala (1992), Camloh (1993, 1999) and Raghavan (1989), liquid media are superior to solid media for early gametophyte development, but the two media have a similar effect on spore germination. In fern cultures, sterilization of spores is necessary before germination procedures (Camloh 1993, Simabukuro et al. 1998).

De Brum \& Randi (2002) analyzed the effect of irradiation and temperature on the germination of sterilized spores of $R$. adiantiformis. The lowest mean germination time $(\overline{\mathrm{t}})$ was observed under $9 \%$ and $17 \%$ of irradiation. The lowest mean germination time $(7.93$ days) was observed at $25 \pm 1^{\circ} \mathrm{C}$ followed by $20 \pm 1{ }^{\circ} \mathrm{C}$. The germination of $R$. adiantiformis was inhibited by higher irradiations and temperatures.

Cryopreservation is a very useful technique for plants of economical interest as an important component in plant biotechnology programs (Benson et al. 1998). This process involves a series of stresses that can disrupt physiology in the plant, promoting modifications in regenerating cultures. The verification of the genetic stability of the material recovered from cryopreservation after storage is desirable for germplasm conservation. Viability is maintained during cryopreservation through cryoprotectants such as dimethyl sulfoxide, glycerol, sucrose and proline (Lynch \& Benson 1991).

Cryopreservation can assist in the conservation of endangered species when used in germplasm banks. According to Pence (2000), fern spores are candidates for long-term germplasm storage at low temperatures including storage in liquid nitrogen. Spores of more than forty fern species survived after exposure to liquid nitrogen (Agrawal et al. 1993, Pence 2000). Rogge et al. (2000) immersed sterilized spores of Dicksonia sellowiana Hook. in liquid nitrogen to analyze the effect of cryopreservation on their viability and observed that they remained viable after being plunged in liquid nitrogen for three months.

This paper investigates the effects of immersion of unsterilized and sterilized spores of Rumohra adiantiformis in liquid nitrogen on some growth characteristics. The effects of cryopreservation on germination, gametophyte and sporophyte growth are assessed to investigate if this process does not alter the Rumohra adiantiformis pattern of initial growth when compared to plant produced from spores stored conventionally under refrigeration at $7 \pm 1{ }^{\circ} \mathrm{C}$.

\section{Materials and methods}

Sporophylls of Rumohra adiantiformis (Forst.) Ching, were harvested in the "Protected Area" of Ilha Comprida, São Paulo, Brazil in July and August, 1999 and March, 2000. Following collection, the fronds were dried on filter paper in an oven at $30^{\circ} \mathrm{C}$ for three days in order to induce sporangia dehiscence. The spores were separated from sporangia by filtering through tissue paper, and were stored in glass jars under refrigeration at $7 \pm 1{ }^{\circ} \mathrm{C}$. Desiccation is one of the usual methods of cell dehydration before freezing in liquid nitrogen (Withers \& Engelmann 1998). The best sterilization method to achieve total decontamination and high germination percentages for this species involves the use of a $15 \%(\mathrm{v} / \mathrm{v})$ solution of commercial sodium hypochlorite ( $2 \%$ of active chlorine) for $10 \mathrm{~min}$ before the spores had been filtered through sterile filter paper by vacuum, washing several times with sterile distilled water and dried in a laminar flow hood for $30 \mathrm{~min}$ (De Brum \& Randi 2002). This method does not affect spore germination of $R$. adiantiformis but under light microscopy, a disruption of the external spore coat was verified.

Samples of sterilized and unsterilized spores stored under refrigeration, were separately placed in $1 \mathrm{~mL}$ sterile polypropylene cryotubes, plunged into liquid nitrogen (LN) cryocans and held for $15 \mathrm{~min}$ (Rogge et al. 2000). After cryogenic treatment, the samples were recovered from the $\mathrm{LN}$ and thawed out by two methods: (a) rapid thawing in a $45^{\circ} \mathrm{C}$ water bath for $5 \mathrm{~min}$; (b) slow thawing at room temperature; the percentage of spore germination after the cryogenic treatment was compared to the control (spores stored under refrigeration at $7 \pm 1{ }^{\circ} \mathrm{C}$ ). Other samples were stored in $\mathrm{LN}$ for 90 days and after storage, they were rapidly or slowly thawed as described above. The percentage of spore germination after cryogenic storage was compared to the control (spores stored under refrigeration at $7 \pm 1{ }^{\circ} \mathrm{C}$ for the same period).

For the germination tests, spores were sown in four conical flasks containing $20 \mathrm{~mL}$ of Mohr's mineral solution as modified by Dyer (Mohr 1956, Dyer 1979) and included Benomyl (50 $\left.\mathrm{mg} \mathrm{L}^{-1}\right)$ to inhibit fungal growth. Flasks were kept in a growth chamber $\left(25 \pm 2{ }^{\circ} \mathrm{C}\right)$ under a 16-hour photoperiod and photon flux density of $30 \mu \mathrm{mol} \mathrm{m} \mathrm{m}^{-2} \mathrm{~s}^{-1}$ provided by cool white fluorescent tubes The level of irradiation was analysed by a quantameter LICOR 250, provided by PAR sensor ( 400 to $700 \mathrm{~nm}$ ). Twenty days after spore inoculation in Dyer's mineral solution, gametophytes 
obtained after spore germination were cultivated in Plantmax ${ }^{\circledR}$ soil. Four samples of $50 \mathrm{mg}$ each $(n=4)$ of 10 week-old gametophytes were treated with methanol, chloroform and water at 12:5:3 v/v (Shannon 1968) for the extraction of soluble sugars which were quantified according to McCready et al. (1950). Sporophytes were observed after 19 weeks of cultivation and were transferred to small pots containing Plantmax ${ }^{\circledR}$ soil for growth analysis. Ten sporophytes from each treatment were analyzed. The experiments were completely randomized.

Germination was scored every two days. One slide was analyzed by light microscopy from each flask $(n=4)$ and 100 spores were counted per slide. Before statistical analyses were done, an asymmetry test (Berquó et al. 2002) was applied to the values of germination percentage which showed that they did not follow a normal distribution. To normalize data, they were submitted to arcsine transformation. To verify the homogeneity of variances, the test of Cochran was applied (Berquó et al. 2002). The mean germination time was calculated for each replication per treatment according to the equation: $\bar{t}=\sum(t n)\left(\sum n\right)^{-1}$, where $t$ is the time in days starting from day 0 (day of spore sowing) and $n$ is the number of spores completing germination on day $t$ (Labouriau 1983). The data were compared using Tukey's multiple range test $(P<0.05)$ for percentage of germination, mean germination time and gametophyte levels of soluble sugars. The number of fronds and the length of the longest frond were recorded after 23 and 39 weeks of cultivation in sporophytes produced from: control spores (CT); spores immersed in liquid nitrogen and rapidly thawed (RT); spores immersed in liquid nitrogen and slowly thawed (ST). The relative growth rate (RGR) of sporophytes was calculated according to the equation $L_{2}-L_{1}\left(t_{2}-t_{1}\right)^{-1}$ (Bernabe et al. 1999) where $L_{2}$ is the $\log _{10}$ of the longest sporophyte frond length at time $2\left(t_{2}=39\right.$ weeks of cultivation starting from spore sowing) and $L_{1}$ is the $\log _{10}$ of the first sporophyte frond length at time $1\left(t_{1}=23\right.$ weeks starting from spore sowing). To verify the homogeneity of variances, the test of Cochran was applied (Berquó et al. 2002). The Kruskal-Wallis test or the Tukey test were applied to analyse number of fronds, height of longest frond and relative growth ratio. Data were analysed by Excel for Windows (Microsoft), Minitab for Windows and Statgraphics software.

\section{Results and Discussion}

According to Pence (2000), nonchlorophyllous spores are similar to orthodox seeds which can be dried and stored for a number of years. Usually, in cultures, fern spores need to be surface sterilized before the germination procedures. Camloh $(1993,1999)$ reported that the best germination occurred when unsterilized spores of Platycerium bifurcatum L. were used, but contamination always occurred after 10 days of culture which was probably the reason for the lower cell number as compared to sterilized spores. Simabukuro et al. (1998) observed that for Cyathea delgadii Sternb. the elimination of bacterial and fungal contaminants was better when the spores were treated with calcium hypochlorite before sowing on medium containing Nystatin. Unfortunately, most treatments that kill contaminant fungi and bacteria also reduce fern spore germination.

After four and six days of culture, the germination of unsterilized spores of $R$. adiantiformis immersed in LN for $15 \mathrm{~min}$, followed by rapid and slow thawing, was higher than the germination of spores not immersed in LN. There was no statistically significant difference between spores immersed or not in LN after eight days of culture (figure 1A). On the other hand, there was a drastic inhibition of spore germination when spores were sterilized before being immersed in $\mathrm{LN}$ for $15 \mathrm{~min}$ (figure 1B). Spores of $R$. adiantiformis have a black coat which is formed by three strata (Tryon \& Tryon 1982); after sterilization they became yellow. Sterilization with commercial sodium hypochlorite seems to destroy the external strata of the spore coat and if employed before cryopreservation it is deleterious to spore germination. The lower mean germination time was observed for unsterilized spores immersed in LN for $15 \mathrm{~min}$ in both thawing methods (table 1). After four days of culture, the spores not immersed in LN, that were held under refrigeration at $7 \pm 1{ }^{\circ} \mathrm{C}$ for 90 days did not germinate, while the percentage of germination for spores held in $\mathrm{LN}$ for 90 days was over $40 \%$ (figure $1 \mathrm{C}$, table 1 ). The germination of cryopreserved spores reached the maximum percentage after 12 days, while spores stored under refrigeration reached their maximum percentage after 16 days. The lower mean germination time was observed for cryopreserved spores in both thawing methods. The germination of cryopreserved spores was also improved in contrast to the spores stored under refrigeration at $7 \pm 1{ }^{\circ} \mathrm{C}$ for 90 days. Possibly, cryogenic treatments improved water uptake, spore imbibition by the breakage of the spore coat and consequently improving the germination time. Rogge et al. (2000) obtained similar results for spores of Dicksonia sellowiana Hook. stored in LN for 90 days. For this species, no difference was observed between spore germination after rapidly or slowly thawing, and spore sterilization before being plunged in LN did not inhibit germination. In fact, for $D$. sellowiana, storage in liquid nitrogen promoted the germination of sterilized spores. Pence (2000) immersed spores of 35 fern species in $\mathrm{LN}$ for one hour, including $R$. adiantiformis. Before 


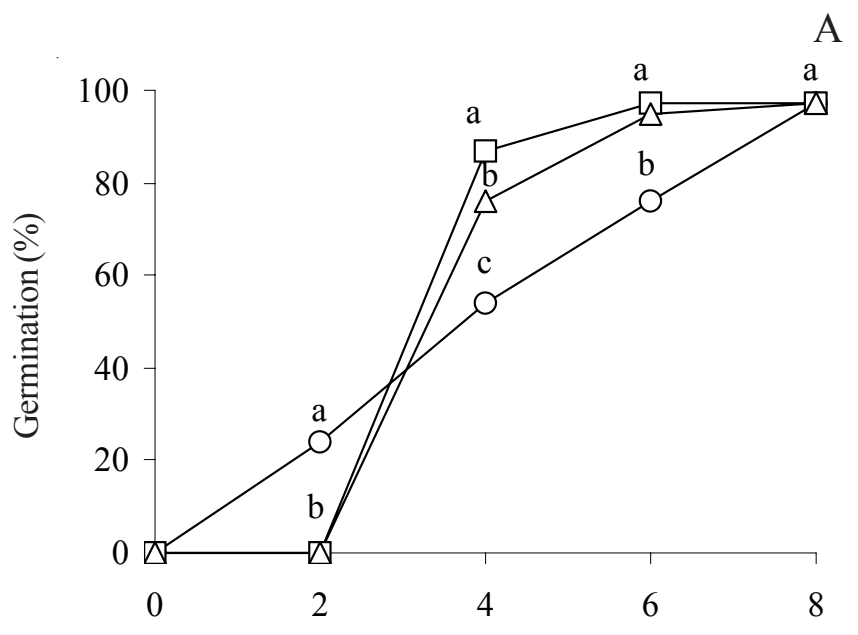

Table 1. Effect of immersion in $\mathrm{LN}$ for $15 \mathrm{~min}$ and 90 days on the mean germination time, of spores of Rumohra adiantiformis (Forst.) Ching. (Mean germination time $=\bar{t}$; $\mathrm{LN}=$ liquid nitrogen; $\mathrm{CT}=$ control; $\mathrm{RT}=$ rapid thawing after immersion in liquid nitrogen; ST = slow thawing after immersion in liquid nitrogen; c.v. $=$ Coefficient of variation; $s^{2}=$ variance; $C=$ Cochran test). Different letters denote statistical differences among treatments (Tukey $P<0.05$ ).

\begin{tabular}{|c|c|c|c|}
\hline Treatment & $\bar{t}$ (days) & c.v. & $s^{2}$ \\
\hline \multicolumn{4}{|c|}{ Immersion in LN - 15 min } \\
\hline CT & $9.13 a$ & 1.12 & 0.010 \\
\hline RT & $7.43 b$ & 1.61 & 0.014 \\
\hline ST & $7.46 b$ & 1.58 & 0.014 \\
\hline C & & & 0.37 \\
\hline \multicolumn{4}{|c|}{ Immersion in LN - 90 days } \\
\hline CT & $12.34 \mathrm{a}$ & 5.09 & 0.039 \\
\hline RT & $8.56 \mathrm{~b}$ & 0.89 & 0.005 \\
\hline ST & $8.56 \mathrm{~b}$ & 1.85 & 0.025 \\
\hline C & & & 0.34 \\
\hline
\end{tabular}

immersion, spores were surface sterilized in a 1:20 dilution of commercial sodium hypochlorite for $5 \mathrm{~min}$. After one hour of immersion in LN, the samples were placed on the benchtop to warm to ambient temperature

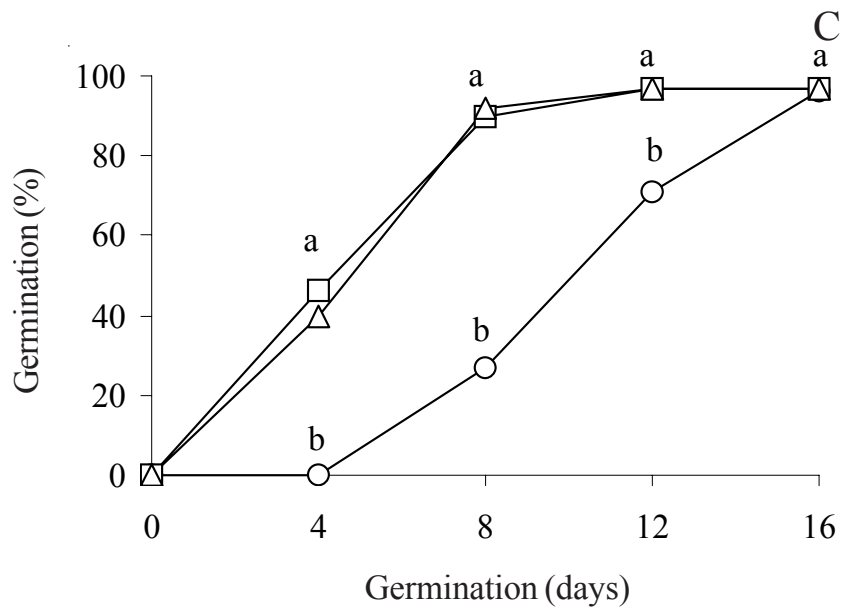

Figure 1. Effect of immersion in $\mathrm{LN}$ for $15 \mathrm{~min}(\mathrm{~A}, \mathrm{~B})$ or 90 days (C), on the germination of spores of Rumohra adiantiformis (Forst.) Ching. (Control $=0$; Rapid thawing after immersion in liquid nitrogen $=\square$; Slow thawing after immersion in liquid nitrogen $=\triangle$ ). Dark symbols are sterilized spores submitted to the same treatments. Different letters denote statistical differences among treatments for each evaluation (Tukey $P<0.05$ ). for $20 \mathrm{~min}$. According to the author, no germination was observed for control spores of $R$. adiantiformis or for cryopreserved spores, but there was no mention of spore age, that could be unviable when the experiment was carried out. On the other hand, 33 other species survived after immersion in LN.

In vitrification-based procedures, cell dehydration is performed before freezing by exposure of plant samples to concentrated cryoprotective media or oven desiccation (Benson et al. 1998, Withers \& Engelmann 1998). Fern spores can endure cryopreservation treatment without the need for additional cryoprotective substances as already observed in some species (Agrawal et al. 1993, Pence 2000, Rogge et al. 2000). Storage in liquid nitrogen of $R$. adiantiformis spores is a feasible method that must be carried out without previous sterilization or addition of a cryoprotectant solution.

Analyses of dry mass weight, photosynthesis and respiration rates, soluble sugars and chlorophyll can be employed to study gametophyte and sporophyte development (Sakamaki \& Ino 1999, Yeh \& Wang 2000, 
Renner \& Randi 2004). Gametophytes of D. sellowiana showed different levels of soluble sugars, chlorophyll and different weight of dry mass under different light and nutritional conditions (Renner \& Randi 2004). According to Sakamaki \& Ino (1999), gametophytes allocated photosynthate for sporophyte growth and it was an important aid before the one-leaf stage. They concluded that the higher photosynthetic rates of gametophytes in the early stage were important for reaching the critical size for sporophyte production in a short time. The levels of soluble sugars of 10 -week-old gametophytes of $R$. adiantiformis resulting from spores stored under refrigeration and spores cryopreserved in LN were not statistically different among treatments (table 2). This observation suggests a normal gametophyte development for $R$. adiantiformis after spore immersion in LN.

After 23 and 39 weeks of cultivation, differences were not observed among treatments as to the number of sporophyte fronds, length of longest frond and RGR (tables 3-5). The data presented in this paper are pioneer. Data concerning growth analyses of fern gametophytes and sporophytes after spore storage in

Table 2. Effect of immersion in LN for $15 \mathrm{~min}$, on the level of soluble sugars of 10-week-old gametophytes of Rumohra adiantiformis (Forst.) Ching originated from cryopreserved spores. $(\mathrm{CT}=$ control; $\mathrm{RT}=$ rapid thawing after immersion in liquid nitrogen; $\mathrm{ST}=$ slow thawing after immersion in liquid nitrogen; $\mathrm{FW}=$ fresh weight; $c . i$. = confidence interval; $s^{2}=$ variance; $C=$ Cochran test). Treatments are not statistically different (Tukey $P<0.05$ ).

\begin{tabular}{lcc}
\hline Treatment & $\begin{array}{c}\text { Soluble sugars } \\
\left(\mathrm{mg} \mathrm{g}^{-1} \mathrm{FW} \pm \text { c.i. }\right)\end{array}$ & $s^{2}$ \\
\hline CT & $2.810 \pm 0.151$ & 0.070 \\
RT & $3.144 \pm 0.207$ & 0.135 \\
ST & $3.125 \pm 0.107$ & 0.033 \\
C & & 0.56 \\
\hline
\end{tabular}

Table 3. Effect of immersion in LN for $15 \mathrm{~min}$, on number of fronds and longest frond length of plants originated from cryopreserved spores of Rumohra adiantiformis (Forst.) Ching. (NF = number of fronds; LF = longest frond length; $\mathrm{CT}=$ control; $\mathrm{RT}=$ rapid thawing after immersion in liquid nitrogen; $\mathrm{ST}=$ slow thawing after immersion in liquid nitrogen; $\mathrm{FW}=$ fresh weight; $c . i .=$ confidence interval; $s^{2}=$ variance; $C=$ Cochran test; $*=$ variances are heterogeneous). Data are means of 10 plants. Treatments are not statistically different $(H=$ Kruskal-Wallis test: $P<0.05)$.

\begin{tabular}{lcccc}
\hline & \multicolumn{4}{c}{ Sporophyte age - 23 weeks } \\
\cline { 2 - 5 } Treatment & $\mathrm{NF}$ & \multicolumn{2}{c}{ LF $(\mathrm{cm})$} \\
$($ Mean \pm c.i. $)$ & $s^{2}$ & & $1.50 \pm 0,39$ & $s^{2}$ \\
\hline CT & $2.40 \pm 0.16$ & 0.49 & $1.70 \pm 0.31$ & 0.39 \\
RT & $2.10 \pm 0.28$ & 1.66 & $1.45 \pm 0.15$ & 2.07 \\
ST & $2.50 \pm 0.15$ & 0.50 & $0.70^{*}$ & 0.47 \\
C & & $0.63^{*}$ & & 0.26 \\
$H$ & & 2.16 & & \\
\hline
\end{tabular}

Table 4. Effect of immersion in LN for $15 \mathrm{~min}$, on number of fronds and longest frond length of plants originated from cryopreserved spores of Rumohra adiantiformis (Forst.) Ching. $\mathrm{CT}=$ control; $\mathrm{RT}=$ rapid thawing after immersion in liquid nitrogen; $\mathrm{ST}=$ slow thawing after immersion in liquid nitrogen; RGR = relative growth rate; c.i.= confidence interval; $s^{2}=$ variance; $C=$ Cochran test. Data are means of 10 plants. Treatments are not statistically different (Tukey $\left.P<0.05\right)$.

\begin{tabular}{|c|c|c|c|c|}
\hline \multirow[b]{2}{*}{ Treatment } & \multicolumn{4}{|c|}{ Sporophyte age - 39 weeks } \\
\hline & $\begin{array}{c}\mathrm{NF} \\
(\text { Mean } \pm c . i .)\end{array}$ & $s^{2}$ & $\begin{array}{c}\mathrm{LF}(\mathrm{cm}) \\
(\mathrm{Mean} \pm \text { c.i. })\end{array}$ & $s^{2}$ \\
\hline CT & $8.80 \pm 0.46$ & 4.62 & $23.90 \pm 0.84$ & 15.66 \\
\hline RT & $8.80 \pm 0.35$ & 2.62 & $19.40 \pm 0.48$ & 5.16 \\
\hline ST & $7.60 \pm 0.52$ & 6.04 & $21.90 \pm 1.20$ & 31.66 \\
\hline$C$ & & 0.45 & & 0.60 \\
\hline
\end{tabular}


Table 5. Effect of immersion in LN for 15 min, on RGR of plants originated from cryopreserved spores of Rumohra adiantiformis (Forst.) Ching. $\mathrm{NF}=$ number of fronds; $\mathrm{LF}=$ longest frond length; $\mathrm{CT}=$ control; $\mathrm{RT}=$ rapid thawing after immersion in liquid nitrogen; $\mathrm{ST}=$ slow thawing after immersion in liquid nitrogen; $c . i=$ confidence interval; $s^{2}=$ variance; $C=$ Cochran test $; *=$ variances are heterogeneous). Data are means of 10 plants. Treatments are not statistically different $(H=$ Kruskal-Wallis test: $P<0.05)$.

\begin{tabular}{lcc}
\hline Treatment & $\begin{array}{c}\text { RGR } \\
(\text { mean } \pm \text { c.i. }) \mathrm{cm} \mathrm{cm}^{-1} \mathrm{wk}^{-1}\end{array}$ & $s^{2}$ \\
\hline CT & $0.077 \pm 0.0025$ & 0.0001 \\
RT & $0.074 \pm 0.0049$ & 0.0006 \\
ST & $0.070 \pm 0.0110$ & 0.0001 \\
$C$ & & $0.75^{*}$ \\
$H$ & & 1.01 \\
\hline
\end{tabular}

LN were not found in the literature. Phenotypic and biochemical preservation has been observed in cryopreserved somatic embryos of palm trees (Engelmann 1991), tomato pollen (Sacks \& Clair 1996) and seeds of cotton (Gonzales-Benito et al. 1998) but were not studied in ferns. The results showed that spores of $R$. adiantiformis immersed in liquid nitrogen were able to germinate and produced plants that showed a normal development during the period analysed.

Acknowledgements - We thank Rudinei Conte (agronomist) for collecting plant material and Robert J. Warren for revising the English manuscript.

\section{References}

AGRAWAL, D.C., PAWAR, S.S. \& MASCARENHAS, A.F. 1993. Cryopreservation of spores of Cyathea spinulosa Wall. ex Hook., an endangered fern. Journal of Plant Physiology 142:124-126.

BENSON, E.E., LYNCH, P.T. \& STACEY, G.N. 1998. Advances in plant cryopreservation technology: current applications in crop plant biotechnology. Agricultural Biotechnological News Information 10:133-141.

BERNABE, N., WILLIAMS-LINERA, G \& PALACIOS-RIOS, M. 1999. Tree ferns in the interior and the edge of a Mexican cloud forest remnant: spore germination and sporophyte survival and establishment. Biotropica 31:83-88.

BERQUÓ, E.S., SOUZA, J.M.P. \& GOTLIEB, S.L.D. 2002. Bioestatística. Editora Pedagógica Universitária. São Paulo.
CAMLOH, M. \& GOGALA, N. 1992. In vitro culture of Platycerium bifurcatum gametophytes. Scientia Horticulturae 51:343-346.

CAMLOH, M. 1993. Spore germination and early gametophyte development of Platycerium bifurcatum. American Fern Journal 83:79-85.

CAMLOH, M. 1999. Spore age and sterilization affects germination and early gametophyte development of Platycerium bifurcatum. American Fern Journal 89:124-132.

DE BRUM, F.M.R. \& RANDI, A.M. 2002. High irradiance and temperature inhibit the germination of spores of the fern Rumohra adiantiformis (Forst.) Ching (Dryopteridaceae). Revista Brasileira de Botânica 25:391-396.

DYER, A.F. 1979. The culture of fern gametophytes for experimental investigation. In The experimental biology of ferns (A.F. Dyer, ed.). Academic Press, London, p.253-305.

ENGELMANN, F. 1991. In vitro conservation of tropical plant germplasm-a review. Euphytica 57:227-243.

FERNÁNDEZ, H., BERTRAND, A.M. \& SANCHEZ-TAMES, R. 1996. Influence of tissue culture conditions on apogamy in Dryopteris affinis. Plant Cell Tissue and Organ Culture 45:93-97.

FERNÁNDEZ, H., BERTRAND, A.M. \& SANCHEZ-TAMES, R. 1997. Gemmation in cultured gametophytes of Osmunda regalis. Plant Cell Reports 16:358-362.

FERNÁNDEZ, H., BERTRAND, A.M. \& SANCHEZ-TAMES, R. 1999. Biological and nutritional aspects involved in fern multiplication. Plant Cell Tissue and Organ Culture 56:211-214.

GONZALES-BENITO, M.E., CARVALHO, J.M.F.C. \& PÉREZ, C. 1998. Effect of desiccation and cryopreservation on the germination of embryonic axes and seeds of cotton. Pesquisa Agropecuária Brasileira 33:17-20.

KATO, M. 1974. A note on the systematic position of Rumohora adiantiformis. Acta Phytotaxomica Geobotanica 26:52-57.

LABOURIAU, L.G. 1983. A germinação das sementes. Série de Biologia. Monografia 24. Organização dos Estados Americanos, Washington.

LYNCH, P.T. \& BENSON, E.E. 1991. Cryopreservation, a method for maintaining the plant regeneration capability of rice cells suspension cultures. In Proceedings of the Second International Rice Genetics Meeting. IRRI, Los Banos, p.321-332.

MCCREADY, R.M., GUGGOLZ, J., SILVIERA, V. \& OWENS, H.S. 1950. Determination of starch and amylose in vegetables. Analytical Chemistry 22:1156-1158.

MILTON, S.J. \& MOLL, E.J. 1988. Effects of harvesting on frond production of Rumohra adiantiformis (Pteridophyta: Aspidiaceae) in South Africa. Journal of Applied Ecology 25:725-743. 
MOHR, H. 1956. Die abhängikeit des protonemawatchstums und der protonemapolarität bei farnem vom licht. Planta 47: 127-156.

PENCE, V.C. 2000. Survival of chlorophyllus and nonchlorophyllous fern spores through exposure to liquid nitrogen. American Fern Journal 90:119-126.

RAGHAVAN, V. 1989. Developmental biology of fern gametophytes. Cambridge University Press, Cambridge.

RENNER, G.D.R. \& RANDI, A.M. 2004. Effects of sucrose and irradiance on germination and early gametophyte growth of the endangered tree fern Dicksonia sellowiana Hook (Dicksoniaceae). Acta Botanica Brasilica 18:375-380.

ROGGE, G.D., VIANA, A.M. \& RANDI, A.M. 2000. Cryopreservation of spores of Dicksonia sellowiana. An endangered tree fern indigenous to South and Central America. Cryoletters 21:223-230.

SACKS, E.J. \& CLAIR, A.S. 1996. Cryogenic storage of tomato pollen: effect on fecundity. HortScience 31:447-448.

SAKAMAKI, Y. \& INO, Y. 1999. Contribution of fern gametophytes to the growth of produced sporophytes on the basis of carbon gain. Ecological Research 14:59-69.
SHANNON, J.C. 1968. A procedure for the extraction and fractionation of carbohydrates from immature Zea mays Kernels. Research Bulletin -Purdue 842:1-8.

SIMABUKURO, E.A., DYER, A.F. \& FELIPPE, G.M. 1998. The effect of sterilization and storage conditions on the viability of spores of Cyathea delgadii. American Fern Journal 88:124-132.

STAMPS, R.H., NELL, T.A. \& BARRET, J.E. 1994. Production temperatures influence growth and physiology of leatherleaf fern. HortScience 29:67-70.

TRYON, R.M. \& TRYON, A.F. 1982. Rumohra. In Fern and allied plants with special reference to Tropical America. (R.M. Tryon \& A.F. Tryon, eds.). Springer, New York, p.487-490.

WHITHERS, L. \& ENGELMANN, F. 1998. In vitro conservation of plant genetic resources. In Agricultural biotechnology (A. Altaman, ed.). Marcel Dekker, New York, p.57-88.

YEH, D.M. \& WANG, H.M. 2000. Effects of irradiance on growth, net photosynthesis and indoor performance of the shade-adapted plant, maidenhair fern. Journal of Horticulture and Science Biotechnology 75:293-298. 